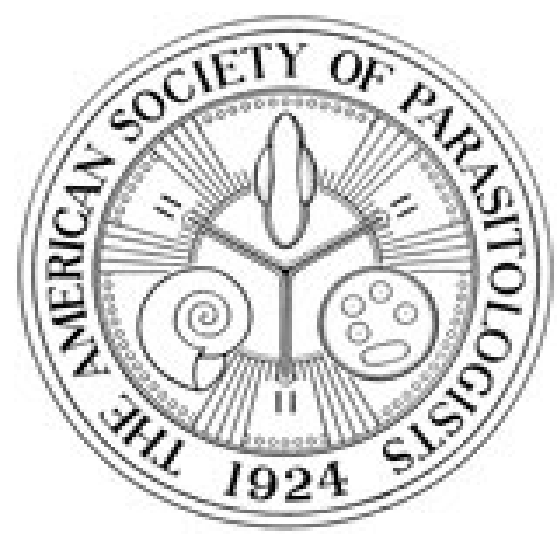

Descriptions of Two New Species of Coccidia (Protozoa: Eimeriidae) and Redescriptions of Eimeria ivensae and Eimeria odocoilei from Captive White-Tailed Deer, Odocoileus virginianus Author(s): David S. Lindsay, Steve J. Upton and Michael B. Hildreth Source: The Journal of Parasitology, Vol. 85, No. 6 (Dec., 1999), pp. 1120-1125 Published by: The American Society of Parasitologists

Stable URL: http://www.jstor.org/stable/3285677

Accessed: 19/06/2014 10:27

Your use of the JSTOR archive indicates your acceptance of the Terms \& Conditions of Use, available at http://www.jstor.org/page/info/about/policies/terms.jsp

JSTOR is a not-for-profit service that helps scholars, researchers, and students discover, use, and build upon a wide range of content in a trusted digital archive. We use information technology and tools to increase productivity and facilitate new forms of scholarship. For more information about JSTOR, please contact support@jstor.org.

The American Society of Parasitologists is collaborating with JSTOR to digitize, preserve and extend access to The Journal of Parasitology. 


\title{
DESCRIPTIONS OF TWO NEW SPECIES OF COCCIDIA (PROTOZOA: EIMERIIDAE) AND REDESCRIPTIONS OF EIMERIA IVENSAE AND EIMERIA ODOCOILEI FROM CAPTIVE WHITE-TAILED DEER, ODOCOILEUS VIRGINIANUS
}

\author{
David S. Lindsay, Steve J. Upton*, and Michael B. Hildreth $\dagger$ \\ Center for Molecular Medicine and Infectious Diseases, Department of Biomedical Sciences and Pathobiology, Virginia-Maryland Regional \\ College of Veterinary Medicine, Virginia Tech, 1410 Prices Fork Road, Blacksburg, Virginia 24061-0342
}

\begin{abstract}
Two new species of Eimeria were observed in the feces of captive white-tailed deer fawns, Odocoileus virginianus, from Alabama. The first new species was easily recognized because of its small size. Sporulated oocysts are spherical, average 10.2 by $10.0 \mu \mathrm{m}$, and lack a micropyle and oocyst residuum. Oocysts contain a polar granule and elongate-ellipsoidal sporocysts that measure 6.7 by $3.1 \mu \mathrm{m}$. A Stieda body is present on the sporocysts. Oocysts were observed in the feces, and gamonts and oocysts were observed in the jejunum of a month-old fawn from Minnesota that died from enteritis due to this species. Oocysts of this small species were present in 5 of the 6 white-tailed deer fawns examined. Oocysts of a second new species are ellipsoidal and average 29.5 by $24.6 \mu \mathrm{m}$. The oocyst encloses an oocyst residuum, polar granule, and elongate-ellipsoidal sporocysts that average 16.0 by $9.0 \mu \mathrm{m}$. A Stieda body and substieda body are present on the sporocysts. Oocysts of the second new species were present in 4 of the 6 white-tailed deer fawns examined. Oocysts of E. ivensae are ovoid or flask-like and average 32.0 by $20.8 \mu \mathrm{m}$. The oocyst wall is rough, contains a micropyle, and encloses elongate-ellipsoidal sporocysts that average 16.5 by 7.8 $\mu \mathrm{m}$. A Stieda body is present on the sporocysts. Oocysts of $E$. ivensae were present in 4 of the 6 white-tailed deer fawns. Oocysts of E. odocoilei are spherical or slightly subspherical and measure 24.7 by $21.5 \mu \mathrm{m}$. They enclose ovoid sporocysts that average 12.7 by $8.8 \mu \mathrm{m}$. A Stieda and substieda body are present on the sporocyst. Oocysts of E. odocoilei were present in 4 of the 6 white-tailed deer fawns.
\end{abstract}

Five species of Eimeria have been described from the feces of deer in the genus Odocoileus. Eimeria ivensae Todd and O'Gara, 1969; E. mccordocki Honess, 1941; and E. odocoilei Levine, Ivens, and Senger, 1967 were described originally from the feces of mule deer, O. hemionus hemionus, whereas E. madisonensis Anderson and Samuel, 1969 and E. virginianus Anderson and Samuel, 1969 were described originally from the feces of white-tailed deer, $O$. virginianus. It has been assumed that both mule deer and white-tailed deer can be hosts for all 5 Eimeria species (Levine and Ivens, 1986).

The present study describes 2 new species of Eimeria from captive white-tailed deer and provides redescriptions of the sporulated oocysts of E. ivensae and E. odocoilei. This is the first report of $E$. ivensae in white-tailed deer.

\section{MATERIALS AND METHODS}

Feces from 6 captive white-tailed deer fawns of undetermined ages were submitted to the Parasitology Laboratory, Department of Pathobiology, College of Veterinary Medicine, Auburn University, Alabama, for fecal examination on 3 July 1996. Microscopic examination of the feces following flotation in Sheather's sugar solution revealed extremely small, spherical coccidial oocysts presumed to be a previously undescribed species in the feces of 5 of the 6 white-tailed deer fawns. Infection with the small coccidial species was present as a monospecific infection in 1 fawn and as mixed infections with what appeared to be 3 other coccidial species in the remaining 4 infected fawns. One fawn had only nematode eggs consistent with Strongyloides papillosus in its sample. Twenty-five unsporulated oocysts of the small spherical species were measured with a calibrated ocular micrometer. When these measurements were compared to those recorded for deer in the genus Odocoileus by Levine and Ivens (1986), it was apparent a new species was present. Feces containing coccidial oocysts were sporulated in $2.5 \%(\mathrm{w} /$ v) potassium dichromate solution in a 4-6 $\mathrm{mm}$ layer in disposable Petri

Received 24 February 1999; revised 21 May 1999; accepted 21 May 1999.

* Division of Biology, Ackert Hall, Kansas State University, Manhattan, Kansas 66506-4901.

$\dagger$ Department of Veterinary Science and Department of Biology and Microbiology, South Dakota State University, Brookings, South Dakota $57007-2142$. dishes at room temperature $22-24 \mathrm{C}$ for $1 \mathrm{wk}$. Fecal samples containing sporulated oocysts were sent to the Division of Biology, Kansas State University, Manhattan, Kansas, for structural characterization and photography by 1 of us (S.J.U.). Examination of sporulated oocysts revealed 2 new species to be present along with oocysts of $E$. ivensae and $E$. odocoilei.

On 8 June 1998, an approximately 1-mo-old white-tailed deer fawn from a captive herd in Minnesota was presented to the Department of Veterinary Science, South Dakota State University, Brookings, South Dakota, for necropsy examination. Examination of a fecal sample revealed oocysts of the small spherical species. Examination of histological tissue sections of jejunum stained with hematoxylin and eosin demonstrated sexual stages of the coccidium.

In the present study, we provide descriptions of the 2 new species and redescriptions of E. ivensae and E. odocoilei. Measurements are in microns, with the mean \pm SD followed by the range and the number (n) of stages measured in parentheses.

\section{DESCRIPTION}

\section{Eimeria zajacae n. sp.}

(Figs. 1-5)

Description: Oocysts spherical, with wall $1 \mu \mathrm{m}$ thick, composed of a single layer, colorless; micropyle and oocyst residuum absent, polar granule present in some oocysts; unsporulated oocysts $10.0 \pm 0.5$ by $9.9 \pm 0.5(8.0-11.0$ by $8.0-11.0, \mathrm{n}=25)$, with $\mathrm{L}: \mathrm{W}$ ratio $1.01 \pm 0.02$ $(1.0-1.1, \mathrm{n}=25)$; sporulated oocysts $10.2 \pm 0.5$ by $10.0 \pm 0.5(9.2$ 11.0 by $9.2-11.0, \mathrm{n}=25)$, with $\mathrm{L}: \mathrm{W}$ ratio $1.02 \pm 0.04(1.0-1.16, \mathrm{n}=$ $25)$; sporocysts elongate-ellipsoidal $6.7 \pm 0.3$ by $3.3 \pm 0.10(6.2-7.2$, $\mathrm{n}=15), \mathrm{L}: \mathrm{W}$ ratio $2.03 \pm 0.10(1.82-2.19, \mathrm{n}=15)$, Stieda body present, indistinct, sub- and parastieda bodies absent; sporocyst residuum composed of 2-6 small spherical granules, scattered or clustered in the center of sporocyst; in situ sporozoites elongate $5.7 \pm 0.3$ by 2.2 $\pm 0.2(5.2-6.2$ by $2.0-2.4, \mathrm{n}=10), 1$ end rounded and the other end tapering, no refractile bodies present.

\section{Taxonomic summary}

Type host: Odocoileus virginianus Zimmerman, white-tailed deer. Other hosts: Unknown. Potentially, Odocoileus hemionus hemionus, mule deer.

Type locality: Alabama.

Other localities: Minnesota.

Prevalence: Five (83.3\%) of 6 white-tailed deer fawns examined were excreting oocysts in their feces. 

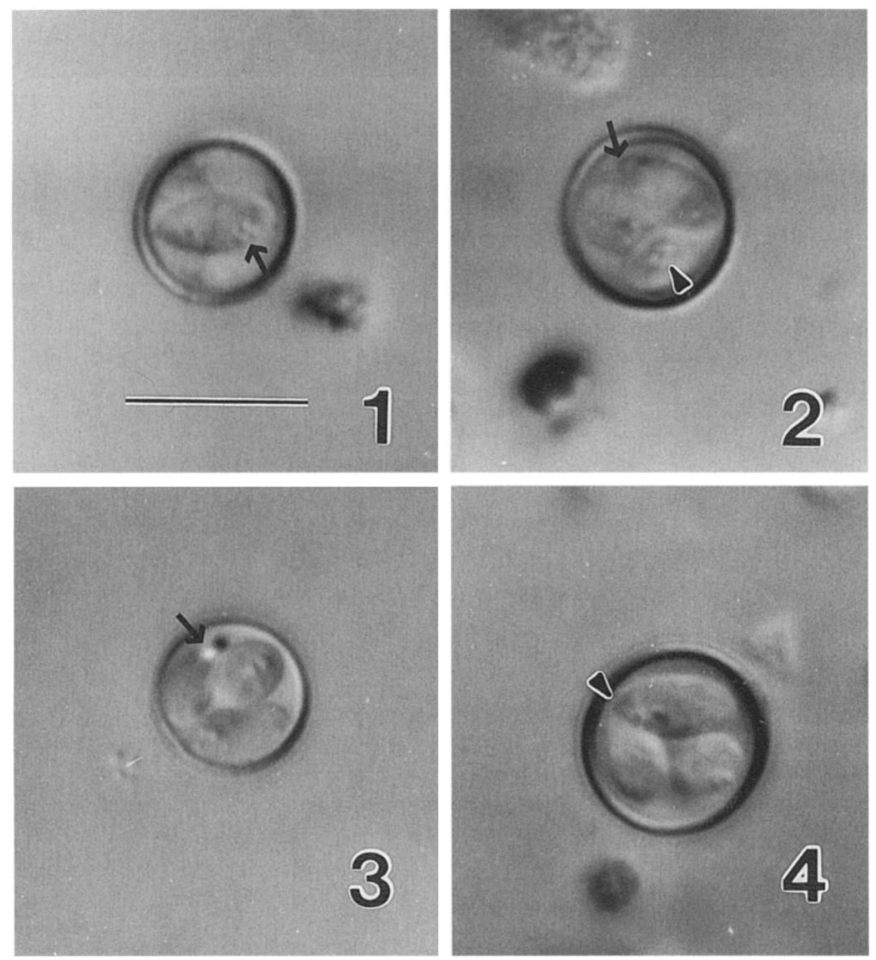

FIGURES 1-4. Nomarski interference contrast photomicrographs of sporulated oocysts of Eimeria zajacae n. sp. Bar $=10 \mu \mathrm{m}$. 1. Oocyst with 1 sporocyst in view. Note the sporocyst residuum (arrow). 2. The Stieda body (arrow) and sporocyst residuum (arrowhead) are visible in sporocysts in this oocyst. 3. A polar granule (arrow) is visible in this oocyst. 4. An indistinct Stieda body is present in the sporocyst in this oocyst. Note the lack of refractile bodies in the sporozoites.

Site of infection: Asexual stages not known. Sexual stage in enterocytes in the jejunum.

Prepatent period: Unknown.

Patent period: Unknown.

Sporulation time: Unknown. Oocysts sporulate in $1 \mathrm{wk}$ at room temperature.

Material deposited: Phototype (see Bandoni and Duszynski, 1988) of sporulated oocysts are deposited in the United States National Parasite Collection (USNPC), Beltsville, Maryland. USNPC 088655.00

Etymology: This species is named in honor of Anne M. Zajac in recognition of her contributions to the field of veterinary parasitology.

\section{Remarks}

The oocysts of $E$. zajacae are much smaller than any previously reported from white-tailed or mule deer. They most closely resemble those of E. madisonensis described from white-tailed deer. Oocysts of E. madisonensis are spherical to subspherical and measure 14-19 by $13-16$ (mean, 16.1 by 15.5 ). The sporulated oocysts of $E$. zajacae are spherical and measure $9.2-11.0$ by $9.2-11.0$ (mean, 10.2 by 10.0). Oocysts of $E$. zajacae contain a polar granule, whereas those of $E$. madisonensis do not. The sporocysts of $E$. madisonensis contain a prominent Stieda body and no residuum, whereas the sporocysts of E. zajacae have an indistinct Stieda body and have a residuum. The sporozoites of $E$. zajacae lack visible refractile bodies, whereas those of $E$. madisonensis have a posterior refractile body.

\section{Eimeria sundermannae $\mathrm{n}$. sp. \\ (Figs. 6-10)}

Description: Oocysts ellipsoidal, with wall $1.8 \mu \mathrm{m}$ thick, composed of a 2 layers, inner layer about 0.6 and outer layer 1.2, colorless; micropyle absent, oocyst residuum composed of a spherical $4.7 \pm 1.0$ by $4.2 \pm 0.7(3.2-6.4$ by $3.3-5.2, \mathrm{n}=7)$ spongy-appearing body appar-

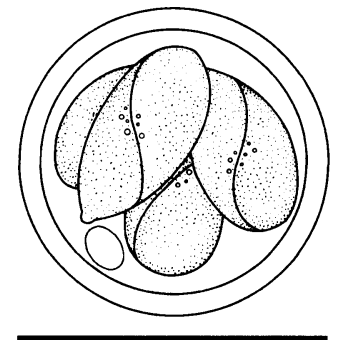

FIGURE 5. Line drawing of Eimeria zajacae. Bar $=10 \mu \mathrm{m}$.

ently attached to the inner oocyst wall, 1 or occasionally 2 polar granules 3 to $5 \mu \mathrm{m}$ present, often attached to a sporocyst or the inner oocyst wall; sporulated oocysts $29.5 \pm 1.8$ by $24.6 \pm 1.5$ (25.6-32.0 by $22.4-$ $28.0, \mathrm{n}=25)$, with $\mathrm{L}: \mathrm{W}$ ratio $1.2 \pm 0.05(1.07-1.28, \mathrm{n}=25)$; sporocysts elongate-ellipsoidal, $16.0 \pm 1.8$ by $9.0 \pm 0.6(14.6-17.6$ by $8.0-$ $9.6, \mathrm{n}=15), \mathrm{L}: \mathrm{W}$ ratio $1.78 \pm 0.10(1.59-1.91, \mathrm{n}=15)$, Stieda body and substieda body present, parastieda bodies absent; sporocyst residuum absent; in situ sporozoites elongate $21.7 \pm 1.4$ by $4.1 \pm 0.2(18.4$ 24.0 by $3.6-4.4, \mathrm{n}=10), 1$ end rounded and the other end tapering, spherical anterior refractile body $2.5 \pm 0.6$ by $2.5 \pm 0.6(1.8-3.2$ by $1.8-3.2, \mathrm{n}=4$ ) present in about $50 \%$ of sporozoites, elongate posterior refractile body $5.5 \pm 0.7$ by $3.9 \pm 0.3(4.8-7.0$ by $3.4-4.2, \mathrm{n}=10)$.

\section{Taxonomic summary}

Type host: Odocoileus virginianus Zimmerman, white-tailed deer Other hosts: Unknown. Potentially, Odocoileus hemionus hemionus, mule deer.

Type locality: Alabama.

Other localities: Unknown.

Prevalence: Four $(66.7 \%)$ of 6 white-tailed deer fawns examined were excreting oocysts.

Site of infection: Unknown. Oocysts recovered in feces.

Prepatent period: Unknown.

Patent period: Unknown.

Sporulation time: Unknown. Oocysts sporulate in $1 \mathrm{wk}$ at room temperature.

Material deposited: Phototype of sporulated oocysts are deposited in the United States National Parasite Collection (USNPC), Beltsville, Maryland. USNPC 088654.00

Etymology: This species is named in honor of Christine A. Sundermann in recognition of her contributions to the field of apicomplexan biology.

\section{Remarks}

None of the Eimeria oocysts described previously from white-tailed or mule deer contain an oocyst residuum. The oocysts of $E$. sunder mannae are 10 to $17 \mu \mathrm{m}$ longer than those of $E$. madisonensis and $E$. zajacae, respectively. Oocysts of $E$. sundermannae most closely resemble those of E. odocoilei described in mule deer by Levine et al. (1967) in size. Oocyst of $E$. odocoilei are $26.0-28.0$ by $22.0-26.0$ (mean, 27.0 by 23.5) according to Levine et al. (1967), whereas those of E. sundermannae measure $25.6-32.0$ by $22.4-28.0$ (mean, 29.0 by 24.0 ). Differences also exist in sporocysts of $E$. sundermannae and $E$. odocoilei (see below under $E$. odocoilei). The oocysts of $E$. sundermannae are ellipsoidal and smaller than the oocysts of E. ivensae, E. mccordocki, and $E$. virginianus, which are ovoid. The oocysts of $E$. ivensae, $E$. mccordocki, and E. virginianus all have a micropyle in their oocysts which is not present in E. sundermannae.

\section{Eimeria ivensae Todd and O'Gara, 1969} (Fig. 11)

Redescription: Oocyst ovoid or flask-like, with wall $1.6-1.8 \mu \mathrm{m}$ thick, composed of a 3 layers, inner layer about 0.5 and outer layers $1.0-1.3 \mu \mathrm{m}$ thick, outermost layer rough and yellowish occasionally separating from the middle layer; micropyle present $1.0-1.2 \mu \mathrm{m}$ thick, oocyst residuum absent, polar granules absent; sporulated oocysts 32.0 \pm 1.4 by $20.8 \pm 1.2(28.8-35.2$ by $17.8-22.4, \mathrm{n}=25)$, with $\mathrm{L}: \mathrm{W}$ ratio 

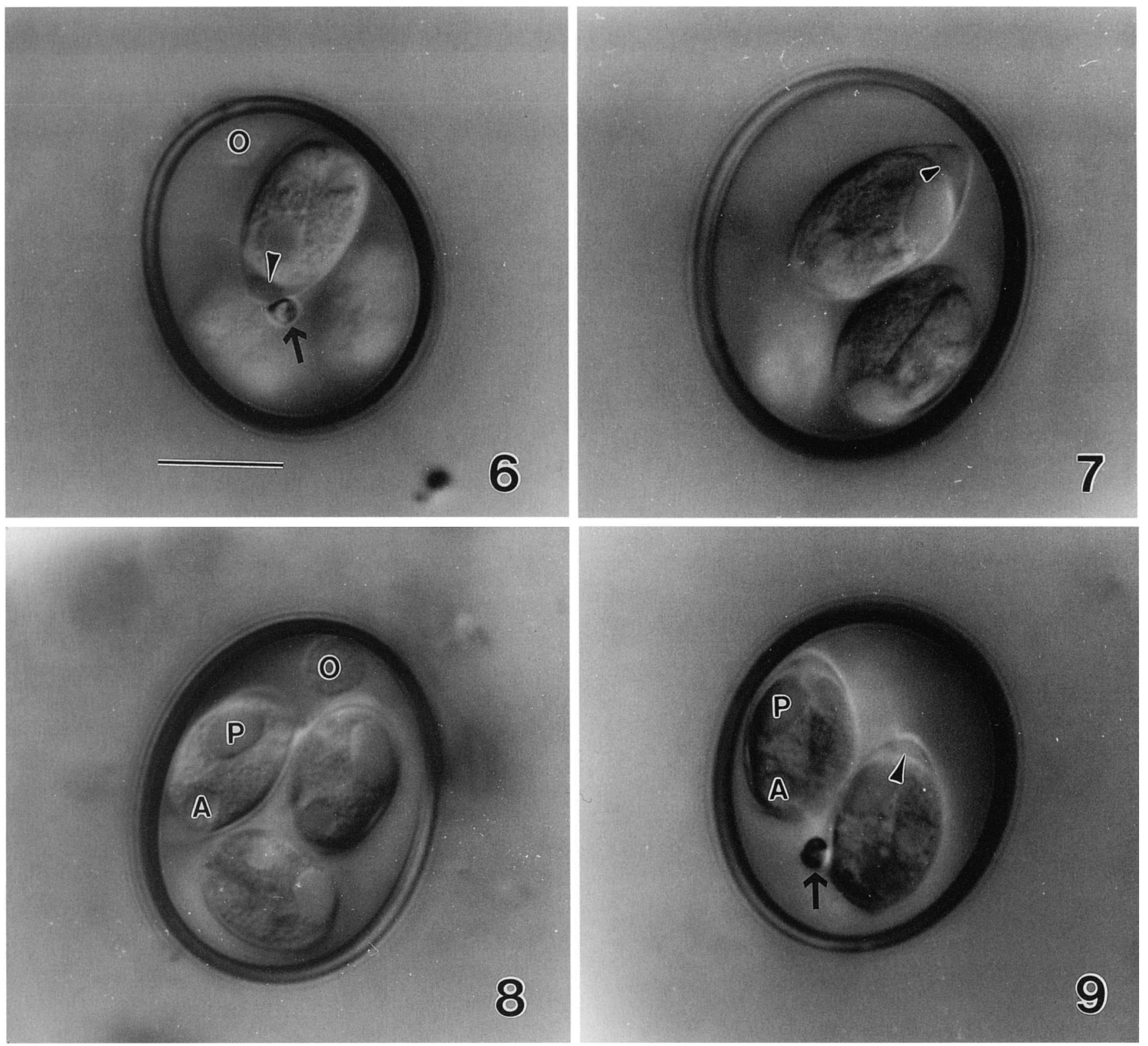

FIGURES 6-9. Nomarski interference contrast photomicrographs of sporulated oocysts of Eimeria sundermannae n. sp. Bar $=10 \mu \mathrm{m} . \mathbf{6}$. Oocyst demonstrating an elongate oocyst residuum $(\mathrm{O})$ and a polar granule (arrow). Note the substieda body (arrowhead) in the 1 sporocyst that is visible. 7. Two sporocysts are visible in this oocyst. Note the substieda body (arrowhead). 8. Oocyst demonstrating a spherical oocyst residuum (O). Note the anterior $(\mathrm{A})$ and posterior $(\mathrm{P})$ refractile bodies in the sporozoite. 9. Oocyst demonstrating a polar granule (arrow). Note the substieda body (arrowhead) in one sporocyst and the anterior (A) and posterior (P) refractile bodies in the sporozoite in the other sporocyst.

$1.54 \pm 0.09(1.39-1.75, \mathrm{n}=25) ;$ sporocysts elongate-ellipsoidal 16.5 \pm 0.6 by $7.8 \pm 0.5(15.2-17.6$ by $7.2-8.2, \mathrm{n}=15), \mathrm{L}: \mathrm{W}$ ratio $2.13 \pm$ $0.17(1.86-2.43, \mathrm{n}=15)$, Stieda body present, but substieda and parastieda bodies absent; sporocyst residuum composed of a few scattered granules or cluster of many granules; in situ sporozoites elongate 20.8 \pm 1.1 by $4.3 \pm 0.4(19.2-21.6$ by $3.8-5.2, \mathrm{n}=10), 1$ end rounded and the other end tapering, spherical anterior refractile body $3.2 \pm 0.5$ by $3.2 \pm 0.5(2.2-4.0$ by $2.2-4.0, \mathrm{n}=10)$, elongate-ellipsoidal posterior refractile body $6.1 \pm 0.4$ by $4.1 \pm 0.4(5.2-6.4$ by $3.6-5.0, \mathrm{n}=10)$.

\section{Taxonomic summary}

Type host: Mule deer, Odocoileus hemionus hemionus.

Other hosts: Odocoileus virginianus Zimmerman, white-tailed deer. Type locality: Montana.

Other localities: Alabama.
Material deposited: Phototype of sporulated oocysts are deposited in the United States National Parasite Collection (USNPC), Beltsville, Maryland. USNPC 088656.00

\section{Remarks}

Todd and O'Gara (1969) originally described this species from mule deer. Our measurements are in general agreement with theirs for oocysts and sporocysts. They reported a shape index of 1.56 for oocysts, whereas we observed a shape index of 1.54. The shape index for sporocysts in their study and our study is 2.13 . They reported a polar granule, but we did not observe a polar granule in the oocysts we examined. They did not provide measurements for sporozoites or the refractile bodies present in the sporozoites but their drawings indicate that the anterior refractile body was spherical and the posterior refractile body was elongate-ellipsoidal as observed in the present study. 


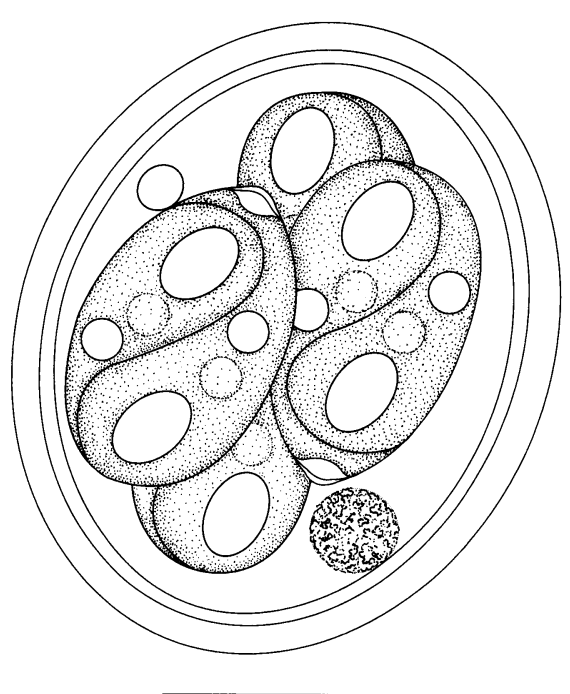

FIGURE 10. Line drawing of Eimeria sundermannae. Bar $=10 \mu \mathrm{m}$.

\section{Eimeria odocoilei Levine, Ivens, and Senger, 1967} (Fig. 12)

Redescription: Oocyst spherical or slightly subspherical, with wall $1.6-1.8 \mu \mathrm{m}$ thick, composed of 2 layers, inner layer $0.6-0.8$ and outer layer 1.6-1.8 $\mu \mathrm{m}$ thick, colorless; micropyle absent; oocyst residuum absent, polar granule $3.2 \mu \mathrm{m}$; sporulated oocysts $24.7 \pm 1.32$ by 21.5 $\pm 1.17(21.6-26.4$ by $19.2-24.0, \mathrm{n}=25)$, with $\mathrm{L}: \mathrm{W}$ ratio $1.15 \pm 0.05$ $(1.07-1.25, \mathrm{n}=25)$; sporocysts ovoid $12.7 \pm 0.47$ by $8.8 \pm 0.32(12.0$ 13.6 by $8.0-9.4)$, L:W ratio $1.44 \pm 0.04(1.36-1.52, \mathrm{n}=15)$, Stieda and substieda bodies present, parastieda body absent; sporocyst residuum composed of a loose cluster of granules; in situ sporozoites elongate $16.6 \pm 1.10$ by $3.1 \pm 0.30(15.4-19.2$ by $2.6-3.4, \mathrm{n}=10), 1$ end rounded and the other end tapering, spherical anterior refractile body $2.0 \pm 0.26$ by $2.0 \pm 0.26(1.6-2.2$ by $1.6-2.2, n=10)$, elongateellipsoidal posterior refractile body $4.1 \pm 0.60$ by $2.9 \pm 0.39$ (3.2-4.8 by $2.4-3.2, \mathrm{n}=10$ ).

\section{Taxonomic summary}

Type host: Mule deer, Odocoileus hemionus hemionus.

Other hosts: Odocoileus virginianus white-tailed deer.

Type locality: Washington.

Other localities: Alabama, Florida, Pennsylvania, Texas, and Wisconsin.

Material deposited: Phototype of sporulated oocysts are deposited in the United States National Parasite Collection (USNPC), Beltsville, Maryland. USNPC 088657.00

\section{Remarks}

Levine et al. (1967) originally described $E$. odocoilei from a mule deer. In the present study sporulated oocysts were 24.7 by 21.5 (21.626.4 by $19.2-24.0$; L:W ratio 1.15 ), whereas Levine et al. (1967) indicated they were 26.9 by $23.5(26.0-28.0$ by $22.0-26.0$; L:W ratio $1.14)$. In the present study sporocysts were ovoid 12.7 by 8.8 (12.013.6 by $8.0-9.4 ; \mathrm{L}: \mathrm{W}$ ratio 1.44 ), whereas Levine et al. (1967) indicated sporocysts were ovoid 13.6 by $9.1(12-15$ by $8-10$; L:W ratio 1.50$)$. Sporocysts of $E$. sundermannae are elongate-ellipsoidal 16.0 by 9.0 (14.6-17.6 by $8.0-9.6 ; \mathrm{L}: \mathrm{W}$ ratio 1.78 ). Levine et al. (1967) did not describe the presence of a substieda body or a sporocyst residuum, but their drawing indicates that both are present in the sporocyst of $E$. odocoilei. We observed a substieda body in the sporocysts of E. odocoilei in the present study and a less prominent sporocyst residuum. We also observed anterior and posterior refractile bodies in sporozoites of E. odocoilei, whereas Levine et al. (1967) described and depicted only a posterior refractile body. No sporocyst residuum is present in the sporocysts of E. sundermannae, further differentiating it from $E$. odocoilei.
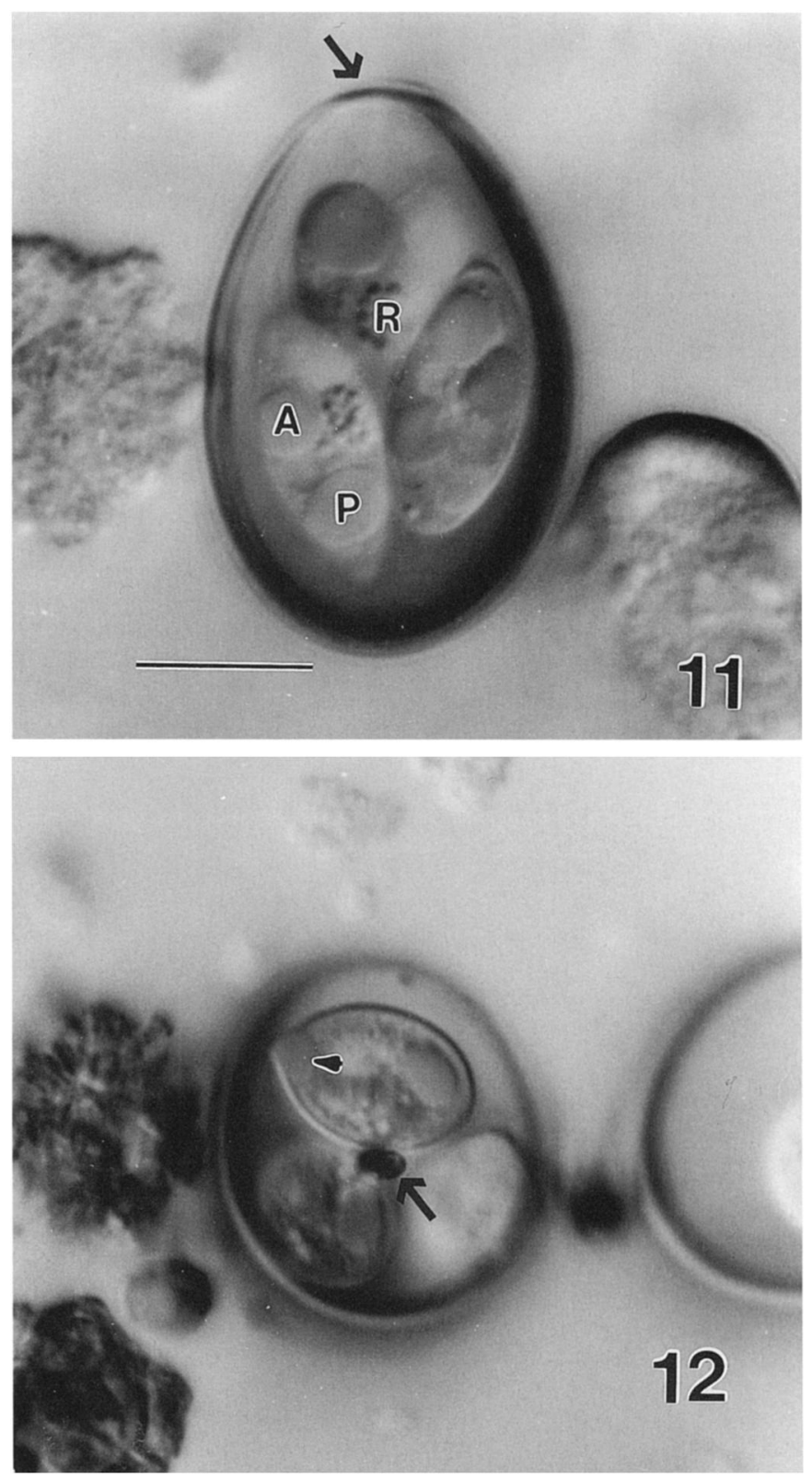

FIGURES 11, 12. Nomarski interference contrast photomicrographs of sporulated oocysts of Eimeria ivensae and Eimeria odocoilei. Bar = $10 \mu \mathrm{m}$. 11. Oocyst of $E$. ivensae demonstrating the micropyle (arrow) in the oocyst wall. Note the sporocyst residuum (R) and anterior (A) and posterior $(\mathrm{P})$ refractile bodies of a sporozoite. 12. Oocyst of Eimeria odocoilei demonstrating a polar granule (arrow). Note the substieda body (arrowhead) in the sporocyst.

Table I provides a comparison of the measurements of sporulated oocysts and sporocysts for Eimeria species described from white-tailed and mule deer.

\section{DISCUSSION}

It is surprising that only 5 species of Eimeria have been reported previously in white-tailed and mule deer, considering the numbers of Eimeria present in domestic ruminants. Few experimental studies have been conducted with coccidia from white-tailed deer. Eimeria mccordocki has been studied in experimentally infected 3-6-wk-old mule deer fawns fed 15.5- 
TABLE I. Comparison of the sporulated oocysts of Eimeria species from white-tailed and mule deer.*

\begin{tabular}{|c|c|c|c|}
\hline Species & $\begin{array}{l}\text { Oocyst } \\
(\mathrm{L} / \mathrm{W})\end{array}$ & $\begin{array}{c}\text { Sporocyst } \\
\text { (L/W) }\end{array}$ & Reference \\
\hline E. ivensae & $\begin{array}{c}32.5 \times 21.0 \\
(1.56)\end{array}$ & $\begin{array}{c}15.8 \times 7.4 \\
(2.13)\end{array}$ & Todd and O'Gara, 1969 \\
\hline E. ivensae & $\begin{array}{c}32.0 \times 20.8 \\
(1.54)\end{array}$ & $\begin{array}{c}16.5 \times 7.8 \\
(2.13)\end{array}$ & Present study \\
\hline E. madisonensis & $\begin{array}{c}16.1 \times 15.5 \\
(1.09)\end{array}$ & $\begin{array}{c}7.5 \times 4.5 \\
(1.66)\end{array}$ & Anderson and Samuel, 1969 \\
\hline E. mccordocki & $\begin{array}{c}35.1 \times 23.5 \\
(1.43)\end{array}$ & $\begin{array}{c}17.6 \times 8.4 \\
(2.01)\end{array}$ & Anderson and Samuel, 1969 \\
\hline E. odocoilei & $\begin{array}{c}26.9 \times 23.5 \\
(1.14)\end{array}$ & $\begin{array}{c}13.6 \times 9.1 \\
(1.50)\end{array}$ & Levine et al., 1967 \\
\hline E. odocoilei & $\begin{array}{c}28.8 \times 25.3 \\
(1.09)\end{array}$ & $\begin{array}{c}13.5 \times 10.3 \\
(1.3)\end{array}$ & Anderson and Samuel, 1969 \\
\hline E. odocoilei & $\begin{array}{c}24.7 \times 21.5 \\
(1.15)\end{array}$ & $\begin{array}{c}12.7 \times 8.8 \\
(1.44)\end{array}$ & Present study \\
\hline E. sundermannae & $\begin{array}{c}29.5 \times 24.6 \\
(1.20)\end{array}$ & $\begin{array}{c}16.0 \times 9.0 \\
(1.78)\end{array}$ & Present study \\
\hline E. virginianus & $\begin{array}{c}49.2 \times 32.6 \\
(1.53)\end{array}$ & $\begin{array}{c}23.6 \times 9.7 \\
(2.36)\end{array}$ & Anderson and Samuel, 1969 \\
\hline E. zajacae & $\begin{array}{c}10.2 \times 10.0 \\
(1.01)\end{array}$ & $\begin{array}{c}6.7 \times 3.1 \\
(2.03)\end{array}$ & Present study \\
\hline
\end{tabular}

* Measurements are means and are in microns. L/W, length/width ratio.

$24.0 \times 10^{3}$ oocysts (Abbas and Post, 1980; Abbas et al., 1987) and 8-mo-old white-tailed deer fawns fed 6.0-10.0 $\times 10^{4}$ oocysts (Conlogue and Foreyt, 1984). Abbas and Post (1980) indicated that this species was pathogenic for mule deer fawns but Conlogue and Foreyt (1984) indicated that it was nonpathogenic for white-tailed deer. The age differences in the fawns may account for the differences in observed pathogenicity. Abbas et al. (1987) observed 2 asexual generations and sexual stages in enterocytes of the ileum from 3 experimentally infected mule deer fawns. We observed a few macrogamonts and oocysts of $E$. zajacae in enterocytes of the jejunum of the white-tailed deer examined in our study. Abbas et al. (1987) indicated that the prepatent period was 19 days and the patent period was 10 days. Conlogue and Foreyt (1984) reported the prepatent period was 10-10.7 days and that the patent period 7.3-9.8 days in white-tailed deer fawns.

Little is known about the prevalence of Eimeria species in white-tailed deer. Anderson and Samuel (1969) found E. virginianus in fecal samples from 4 of $146(3 \%)$ white-tailed deer from Pennsylvania and 5 of $683(<1 \%)$ fecal samples from white-tailed deer from Wisconsin. It is unlikely the sporulated oocysts of this species can be confused with any other present in white-tailed or mule deer because its oocysts are large (49.2 by $32.6 \mu \mathrm{m}$ ) and thick walled and enclose sporocysts that have sporozoites with 4 refractile bodies (Anderson and Samuel, 1969). Oocysts of E. madisonensis were found in 3 of 68 $(<1 \%)$ fecal samples from white-tailed deer from Iowa and Wisconsin (Anderson and Samuel, 1969). Samuel and Trainer (1971) found oocysts of E. mccordocki in 49 of 374 (13\%) and E. odocoilei in 1 of $374(<1 \%)$ fecal samples from white-tailed deer in Texas. Forrester $(1988,1992)$ found that $27(10 \%)$ of 261 fecal samples collected from white-tailed deer from southern Florida contained E. odocoilei (3\%), E. madisonensis (1\%), E. mccordocki (5\%), and E. virginianus (1\%).
As more wild ruminants are raised in confinement, it is likely that new disease conditions will develop in these animals (Bruning-Fann et al., 1997). Confinement is a contributing factor to the development of coccidiosis. The white-tailed deer fawn that died in the present study also had bacterial enteritis, so a direct link to its E. zajacae infection could not be established. It is possible that coccidiosis may emerge as a disease of captive-raised white-tailed deer.

\section{ACKNOWLEDGMENTS}

The contribution of S.J.U. was supported in part by NSF PEET grant DEB-9521687. We thank Terry Lawrence, Virginia-Maryland Regional College of Veterinary Medicine, Blacksburg, Virginia, for drawing the oocysts.

\section{LITERATURE CITED}

AbBas, B., And G. Post. 1980. Experimental coccidiosis in mule deer fawns. Journal of Wildlife Diseases 16: 565-570.

, AND W. C. MARQuARDT. 1987. Merogony and gametogony of Eimeria mccordocki (Protozoa, Eimeriidae) in mule deer, Odocoileus $h$. hemionus. Veterinary Parasitology 24: 1-5.

Anderson, D. R., AND W. M. Samuel. 1969. Eimeria (Protozoa: Eimeriidae) from white-tailed deer Odocoileus virginianus in Pennsylvania, Texas, and Wisconsin, with descriptions of two new species. Bulletin of the Wildlife Disease Association 5: 351-356.

Bandoni, S. M., AND D. W. DuszYNSKI. 1988. A plea for improved presentation of type material for coccidia. Journal of Parasitology 74: $519-523$

Bruning-Fann, C. S., K. L. Shank, And J. B. Kaneene. 1997. Descriptive epidemiology of captive cervid herds in Michigan, USA. Veterinary Research 28: 295-302.

Conlogue, G. C., AND W. J. Foreyt. 1984. Experimental infections of Eimeria mccordocki (Protozoa, Eimeriidae) in white-tailed deer. Journal of Wildlife Diseases 20: 31-33.

FORRESTER, D. J. 1988. Intestinal coccidia of white-tailed deer in southern Florida. Journal of Wildlife Diseases 24: 369-370. 
1992. Parasites and diseases of wild mammals in Florida. University Press of Florida. Gainesville, Florida, $459 \mathrm{p}$

LeVINE, N. D., AND V. IVENS 1986. The coccidian parasites (Protozoa, Apicomplexa) of Artiodactyla. Illinois Biological Monographs 55: $1-265$. the mule deer, Odocoileus h. hemionus in Washington. Journal of Protozoology 14: 455-456.
Samuel, W. M., and D. O. Trainer. 1971. Some ecologic factors influencing Eimeria mccordocki Honess 1941 in white tailed deer Odocileus viginianus (Zimmermann). Journal of Protozoology 18: 306-308.

TodD, K. S., AND B. W. O'GARA. 1969. Eimeria ivensae sp. n. from the mule deer, Odocoileus hemionus hemionus in Montana. Transactions of the American Microscopical Society 88: 589-591. 